\title{
RESENHA
}

\section{Da substituição de importações a substituição de exportações*}

ANDRÉ LUIZ REIS DA SILVA**

O Modelo Substitutivo de Importações constituiu um conceito analítico "consagrado" de análise do processo de desenvolvimento brasileiro no século XX, em especial após a Revolução de 1930 e do período pós-Segunda Guerra Mundial. Também foi um modelo perseguido pelos sucessivos governos nesse mesmo período, impulsionado pelo desenvolvimento do capitalismo brasileiro. Entretanto, seus impasses e vicissitudes não haviam ainda sido inteiramente analisados, bem como sua alteração para um Modelo Substitutivo de Exportaçóes, quando o amadurecimento do desenvolvimentismo brasileiro. Nesse sentido, o livro da professora de Relações Internacionais Heloísa Machado da Silva procura desvendar as articulações entre modelo de desenvolvimento, política externa e comércio exterior, a partir dos conceitos de Substituição de Importaçōes e Substituição de Exportaçōes.

O livro, baseado na tese de doutorado da autora, defendida na UnB, inicia com um prefácio de Amado Cervo, que orientou a pesquisa. Conciso e provocador, o prefácio abre, de forma contundente, o debate-guia do livro (e, portanto, da pesquisa) de Heloísa Machado. $\mathrm{Na}$ introdução, a autora desvela as correntes teóricas sobre comércio internacional e desenvolvimento, dos clássicos aos neoclássicos, passando pelos keinesianos e cepalinos. O fio condutor é tentar observar as principais teses que orientam os governos nas conseqüências e resultados da política de comércio exterior.

No meio desta controvérsia econômica, o objetivo do trabalho é, recuperando a perspectiva histórica, precisamente permitir uma avaliação mais abrangente de temas centrais da política de comércio exterior brasileira neste período, cujos interesses giravam em torno do nacional-desenvolvimentismo, no rearranjo da pauta de importações, da necessidade de diversificação da pauta de exportações e do papel desempenhado pela diplomacia como instrumento

\footnotetext{
* SILVA, Heloisa Machado. Da substituição de importações a substituição de exportaçōes: a política de comércio exterior brasileira de 1945 a 1979. Porto Alegre: Ed. UFRGS, 2004, 485p., ISBN 85-7025-792-9.

** Professor das Faculdades Porto-Alegrenses - Fapa, pesquisador associado do Núcleo de Estratégia e Relações Internacionais da Universidade Federal do Rio Grande do Sul - Nerint-UFRGS e Doutorando em Ciência Política pela mesma universidade.
} 
de promoção comercial. A recuperação histórica permitiu caracterizar a política de comércio exterior brasileira pela idéia-força do nacional-desenvolvimentismo.

A autora dividiu o livro em sete capítulos, correspondendo às diversas fases de comércio exterior elencadas. Assim, o primeiro capítulo é dedicado a reestruturação da economia brasileira no imediato pós-guerra (1945-1950), onde foram analisados os problemas relativos ao balanço de pagamentos, com o malogro da política econômica externa do governo Dutra, o estabelecimento do controle seletivo de importações e a implantação do regime de câmbio com licença prévia. No segundo capítulo, foram analisadas as dificuldades na relação com os Estados Unidos, a luta pela manutenção de uma política cafeeira rentável aos exportadores, o nacionalismo como opção para o desenvolvimento, o estabelecimento de um plano de metas, a deterioração dos termos de intercâmbio e a acentuação do recurso ao capital estrangeiro. Já no terceiro capítulo abordou a tentativa de captação de recursos para o desenvolvimentismo de Kubistschek, a Operação Pan-Americana, os primeiros passos da integração latino-americana, a rivalidade comercial com o continente africano e o ensaio multilateral do comércio exterior brasileiro.

Os três capítulos seguintes tratam da formulação e desenvolvimento do modelo substitutivo de exportações. Assim, o quarto capítulo analisa a Política Externa Independente, base inicial do Modelo Substitutivo de Exportaçōes, a ampliação das relações comerciais no período, bem como as dificuldades e adversidades do colapso do populismo. No quinto capítulo, temos uma interessante abordagem do governo Castelo Branco, por meio da análise da interrupção da Política Externa Independente e a paulatina recuperação, sob novas bases, do Modelo Substitutivo de Importações. O sexto capítulo é dedicado à chamada concretização do Modelo Substitutivo de Exportações, correspondendo basicamente aos governos Costa e Silva e Médici. O sétimo capítulo trata do amadurecimento do Modelo Substitutivo de Exportações, ocorrido em uma conjuntura adversa, marcada pelas dificuldades que atingiram a economia brasileira na segunda metade da década de 1970. Em meio a essa conjuntura, verificam-se os crescentes atritos com Washington e a busca de consolidação de parceiras nos mais diversos continentes. Entretanto, a consolidação do Modelo Substitutivo de Exportações não fora capaz de reverter a grave e nociva distorção das contas externas do país, que causaram efeitos globais e nefastos para a fase posterior das relaçōes internacionais do Brasil.

Para a autora, no período 1945-1979, as consideraçōes ligadas ao comércio exterior/desenvolvimento tornaram-se o âmago das decisões diplomáticas. Nesse sentido, as opções de política externa e as grandes decisões foram regidas por essa dicotomia, o que acabou dando à diplomacia brasileira, em termos econômicos, um caráter universalista e estratégico. Esse caráter resultou do malogro do liberalismo econômico do governo Dutra e da constatação de que o multilateralismo do comércio internacional estabelecia princípios que os 
governos dos países desenvolvidos passariam rapidamente a burlar, protegendo os seus mercados. O marco na passagem da substituição de importações para a substituição de exportações foi o ano de 1961, com a inauguração da Política Externa Independente. A partir desse ano, o Itamaraty converteu-se no eixo fundamental para a promoção de manufaturas brasileiras no exterior. Justamente em 1961, foi criado, no Itamaraty, o Serviço de Propaganda e Expansão Comercial do Brasil (Sepro), modificando os escritórios comerciais e qualificando o corpo de diplomatas para essas funções no exterior. No período 1961-1979, com um parque industrial implantado que clamava por mercados externos, a política externa brasileira reforçou seu universalismo.

O livro traz, de forma bem fundamentada, as influências mútuas entre o comércio exterior, o modelo de desenvolvimento e a política externa brasileira. Mostra claramente o esforço de reconversão do Itamaraty na promoção comercial, tendo como eixo central o desenvolvimento do país. Não obstante, será interessante uma posterior análise sobre o período pós-1979, já que a diplomacia do nacional-desenvolvimentismo iria ser mantida pelo menos até meados dos anos 80, em meio a um contexto internacional adverso. Por outro lado, é relevante considerar o contexto analisado (1945-1979) como o período no qual o capitalismo assumiu uma maior concentração e centralização internacional do capital, com a ampliação das multinacionais e a transferência de parques industriais para regiōes periféricas. Nesse sentido, é importante ponderar se a política de desenvolvimento industrial brasileiro constituía uma adaptação propositiva ou meramente passiva às transformações que o capitalismo vinha sofrendo em nível internacional.

Assim, a obra de Heloísa Machado da Silva nos oferece uma oportunidade ímpar para refletir sobre os impasses no modelo de desenvolvimento brasileiro, a partir das liçôes e questôes suscitadas pelo estudo acurado das principais dimensões da política de comércio exterior e do papel da diplomacia neste processo. Enfim, constitui um livro que contribui decisivamente para a análise da política externa do período. 